\title{
Essay
}

\section{DO THEORIES OF STATUTORY INTERPRETATION MATTER? A CASE STUDY}

\author{
Daniel A. Farber
}

A perceptive observer once remarked that nothing so important in law had received as little attention as statutory interpretation. ${ }^{1}$ But if nothing else has changed about statutory interpretation, surely this deficiency has been remedied: the subject has now received intensive consideration from scholars and judges alike. ${ }^{2}$ Yet the debate still has its gaps. As another perceptive observer said more recently, "[t]oo often, the approach of legal scholars to the 'ought' is insufficiently informed by a systematic study of the 'is,' with the result that unhelpful abstractions and, occasionally, caricatures, provide the basis for normative analysis.",

To better understand the relation between "is" and "ought"-or between theory and practice-it is enlightening to examine how theory shapes the decisions of sophisticated judges. This Article will explore some decisions of two distinguished judges who are on the forefront of the theoretical debates, Richard Posner and Frank Easterbrook. ${ }^{4}$ In terms of their theoretical writings about interpretation, Posner (a leading pragmatist) and Easterbrook (a leading textualist) are as far apart as two judges could be. How does the theoretical conflict affect their work as judges? Because the two sit on the same court, I will focus on cases in which they have disagreed

- Henry J. Fletcher Professor and Associate Dean for Research and Faculty, University of Minnesota Law School. Frank Easterbrook, Phil Frickey, Gil Grantmore, Bob Hudec, Miranda McGowan, Richard Posner, Jeff Rachlinski, Bob Summers, and Suzanna Sherry provided helpful comments on earlier drafts. Katie Moerke provided especially helpful research assistance.

I See Robert Weisberg, The Calabresian Judicial Artist: Statutes and the New Legal Process, 35 STAN. L. REV. 213, 213 (1983).

2 See William N. ESKRIDGe, JR. \& PhiliP P. FRickey, Cases and Materials on legislation: STATUTES AND THE CREATION OF PUBLIC POLICY (2d ed. 1995) (collecting numerous materials on interpretation). For an excellent introduction to the theoretical issues, see KENT GREENAWALT, LEGISLATION: STATUTORY INTERPRETATION: 20 QUESTIONS (1999).

3 Jane S. Schacter, The Confounding Common Law Originalism in Recent Supreme Court Statutory Interpretation: Implications for the Legislative History Debate and Beyond, 51 STAN. L. REV. 1, 56 (1998).

4 An empirical study lists Posner and Easterbrook among the five most prestigious federal circuit judges in the United States as measured by references to them by name in the opinions of other judges. See David Klein \& Darby Morrisroe, The Prestige and Influence of Individual Judges on the U.S. Courts of Appeals, 28 J. LEGAL. STUD. 371, 381 (1999). 
about the meaning of a statute, with an eye to learning how their sharp theoretical disputes enter into these decisions. ${ }^{5}$ Making no pretense of a general familiarity with their voluminous judicial output, ${ }^{6} \mathrm{I}$ will analyze only statutory cases in which they have joined battle, and even here I do not attempt an exhaustive survey.

Reading these opinions makes it clear that the conventional view of their theories is an oversimplification: Posner is capable of being quite "formalistic," while Easterbrook's version of textualism is sometimes quite "pragmatic." Some years ago, I complained that Supreme Court opinions too often were missing the "play of intelligence," meaning not that they were stupid, but that they were intellectually flabby, lacking in imagination and insight. ${ }^{8}$ Alas, this remains even more true today; the past Term's opinions on statutory interpretation were particularly dismal. The same cannot be said of the opinions I will be discussing. Despite their often humdrum subjects, they crackle with intellectual energy. 'For that reason alone, they are well worth study. But they also contain some lessons about how theory and practice relate.

Besides their intrinsic interest, the cases in which Posner and Easterbrook disagree also provide a test of how closely theories of interpretation are linked to outcomes. Somewhat to my surprise, I have concluded that the effect is quite limited. ${ }^{10}$ Posner and Easterbrook are as serious about legal theory (and certainly as capable of theoretical analysis) as any two judges we are ever likely to see. Their theories of interpretation are sharply opposed. In the four opinions that I examine in detail, ${ }^{11}$ however, these

5 Thus, this article can be seen as a preliminary response to Cass Sunstein's call for empirical research on the performance of formalist judges. See Cass R. Sunstein, Must Formalism Be Defended Empirically?, 66 U. CHI. L. Rev. 636, 655 (1999).

6 As of August 24, 1999, Posner and Easterbrook have sat together in the Seventh Circuit on 867 reported cases. Appendix B sets out the search methods used to derive this and other results.

7 A complete list of the cases in which they have taken opposite sides as of August 24, 1999 is found in Appendix A along with a brief description of each case.

8 See Daniel A. Farber, Missing the "Play of Intelligence," 36 WM. \& MARY L. REV. 147, $149-58$ (1994).

9 If, as he said in his confirmation hearing, Judge Robert Bork was in search of an intellectual feast, he might have done better to put in for a transfer to the Seventh Circuit rather than try for a spot on the Supreme Court. See Nomination of Robert H. Bork to Be Associate Jistice of the Supreme Court of the United States: Hearings Before the Senate Comm. on the Judiciary, 100th Cong. 854 (1987).

${ }^{10}$ Posner might be less surprised. He has devoted a recent book to attacking the practical relevance of moral and constitutional theory, and might well be willing to draw the same conclusion about theories of interpretation. See RICHARD A. POSNER, THE PROBLEMATICS OF MORAL AND LEGAL TheORY (1999).

"The search produced one other case that deserves particular mention. See Marozsan $v$. United States, 852 F.2d 1469, 1478-79 (7th Cir. 1988) (en banc). The case involved a statute barring judicial review of veterans benefits, and the issue was whether the statute covered procedural due process claims. Although Posner and Easterbrook wrote interesting opinions on opposite sides of this issue, the majority's view was strongly shaped by sharp constitutional concerns that make it difficult to treat the disagreement as purely one of statutory interpretation. See id.

Another particularly interesting case, Hope Clinic v. Ryan, 197 F.3d 876 (7th Cir. 1999) (en banc), was decided while this article was at press. Hope Clinic involved facial challenges to two state laws 
theoretical differences seem to have had only a marginal relationship with outcomes. Moreover, it turns out that Posner and Easterbrook are somewhat less likely to dissent from each other's opinions than is typical for judges on their court, the Seventh Circuit.

There is, in short, a resounding absence of evidence that these judges' sharp theoretical difference has any substantial effects on their judicial votes. This means either that their theoretical difference does not matter or that it is precisely offset by their similarities in other respects. Like other federal appellate judges, they agree on the outcome in the vast majority of the cases on which they sit. At the very least, it seems fair to say, the differences in their work as judges are dramatically smaller than the differences in their jurisprudential writings.

\section{COMPETING THEORIES OF STATUTORY INTERPRETATION}

One purpose of this section is to serve as the obligatory "Part I," retracing ground familiar to scholars but not to other readers. But it also has another purpose: to raise the question of whether, in the end, this conventional account really is satisfactory. When we look at the judicial work of two leading participants in these debates, an important question that arises is whether the conventional understanding of the formalism/pragmatism dispute really does justice to the complexity and subtlety of their views, as revealed in their judicial practice. One reason we may tend to overemphasize the link between theory and practice is that we have a tendency to oversimplify the theories (particularly those we disfavor).

\section{A. Textualism/Formalism}

The conventional approach to statutory interpretation has involved an eclectic mix of reliance on text, canons of interpretation, legislative history, purpose, and public policy. ${ }^{12}$ In the 1980 s, formalists mounted a challenge

purporting to ban "partial birth abortions" ("dilution and extraction" or D \& X procedures). Id. at 861. There were two major issues. First, Easterbrook's majority opinion holds that banning this particular method does not create an "undue burden" on the right to an abortion or endanger women's health. See id. at 871. Posner disagreed on this constitutional issue. See id. at 878-82. Second, as written, the laws arguably also banned other abortion methods that are clearly protected under current constitutional doctrine. See id. at 873-74. This aspect of the case produced an intriguing debate between Posner and Easterbrook. Easterbrook, on behalf of the majority, crafted a novel judicial remedy. He upheld the "core" application of the statutes to "partial birth abortions" but enjoined their application to any other procedures, pending possible later definitive interpretation of the statutes by the state courts. See $i d$. at 876. Posner protested that this remedy was unsupported by precedent and exceeded the court's powers under Article III. See id. at 876-78. While the constitutional portion of Posner's opinion seems more pragmatic than Easterbrook's in its focus on the political context and medical implications of the state laws, his treatment of the remedial issue is more formalist than Easterbrook's innovative injunctive scheme. See id. at 876-78, 886-87.

12 For a fuller discussion, see William N. Eskridge, Jr. \& Philip P. Frickey, Statutory Interpretation as Practical Reasoning, 42 STAN. L. REV. 321, 324-45 (1990). A good description of the conventional 
to this conventional approach in favor of a tightly structured method of statutory interpretation." As William Eskridge observes, "[f]ormalism posits that judicial interpreters can and should be tightly constrained by the objectively determinable meaning of a statute; if unelected judges exercise much discretion in these cases, democratic governance is threatened."14 Textualists stress that the proper forum for policy making in a democratic society is the legislature. The role of judges is to apply statutes as they are written, without regard to concepts such as statutory purpose or legislative intent, and without attempting to adapt statutes to changing times. Judge Easterbrook himself has made this point with particular clarity: "Laws are designed to bind, to perpetuate a solution devised by the enacting legislature, and do not change unless the legislature affirmatively enacts something new. ... Law does not change in meaning as the political culture changes."15 Several corollaries exist to Easterbrook's thesis.

First, textualists are highly suspicious of the use of legislative history in statutory interpretation. "It is, to begin with, irrelevant, since "the law" consists of the statute Congress passed, not the ideas in the minds of the legislators. ${ }^{17}$ Moreover, to consult legislative history weakens the separation of powers, because the President can veto only the language of the bill, not the unwritten intentions of its supporters. ${ }^{18}$ Furthermore, allowing reference to legislative history asks judges to undertake historical research for which they are ill-suited, ${ }^{19}$ empowers judges to enact their own policy choices at the expense of the statutory language, ${ }^{20}$ and licenses individual legislators and their staffs to make law without obtaining the full support of their colleagues. ${ }^{21}$

judicial approach can be found in ABNER J. MIKVA \& ERIC LANE, AN INTRODUCTION TO STATUTORY INTERPRETATION AND THE LEGISLATIVE PROCESS 456 (1997).

13 See, e.g., Frank H. Easterbrook, Text, History, and Structure in Statutory Interpretation, 17 HARV. J.L. \& PUB. POL'Y 61 (1994) [hereinafter Easterbrook, Text \& History]; see also, e.g., Robert S. Summers \& Geoffrey Marshall, The Argument from Ordinary Meaning in Statutory Interpretation, 43 N. IR. L.Q. 213 (1992) (defending textualism as a primary interpretative tool). "Formalism" has sometimes served as a pejorative term in legal debates. It should be clear, I hope, that I regard "formalist" as a descriptive rather than evaluative term.

14 William N. Eskridge, Jr., The New Textualism, 37 UCLA L. REV. 621, 646 (1990).

15 Easterbrook, Text \& History, supra note 13, at 69.

${ }^{16}$ For a survey of the debate over legislative history, see Schacter, supra note 3, at 6-9.

17 See id. at 8.

18 See Thompson v. Thompson, 484 U.S. 174, $191-92$ (1988) (Scalia, J., concurring) (writing that legislative history is a poor substitute for bicameralism and presentment); W. David Slawson, Legislative History and the Need to Bring Statutory Interpretation Under the Rule of Law, 44 STAN. L. REV. 383, 404-05 (1992).

19 See Adrian Vermeule, Legislative History and the Limits of Judicial Competence: The Untold Story of Holy Trinity Church, 50 STAN. L. REv. 1833, 1858 (1998).

20 See Immigration \& Naturalization Serv. v. Cardoza-Fonseca, 480 U.S. 421, $452-53$ (1987) (Scalia, J., concurring); Kenneth W. Starr, Observations About the Use of Legislative History, 1987 DUKE L.J. 371,376 (1987).

${ }^{21}$ See Slawson, supra note 18, at 397-98. 
Second, textualists, such as Easterbrook, maintain that the concept of legislative intent is incoherent. A legislature is a collective body, whose members are often in disagreement and have no coherent set of preferences. Statutes are often the result of a deal between opposing interests. "Legislation is compromise. Compromises have no spirit; they just are."22 When the legislature has failed to speak clearly to an issue, it is bootless for a court to try to fill the gap. When the court reaches the limits of a statute's clear instructions, the only thing to do is to put the statute aside and admit that it provides no basis for ruling. ${ }^{23}$ As Easterbrook puts it:

Hard questions have no right answers. Let us not pretend that texts answer every question. Instead we must admit that there are gaps in statutes, as in the law in general. When the text has no answer, a court should not put one there on the basis of legislative reports or moral philosophy-or economics! Instead the interpreter should go to some other source of rules, including administrative agencies, common law, and private decision. ${ }^{24}$

Refusing to stretch statutory language or fill gaps has another major advantage, according to formalists. Knowing that courts will follow only their plain language, legislators will have an incentive to draft statutes carefully and precisely. ${ }^{25}$ Through this strategy, formalists argue, courts help to foster the democratic process. ${ }^{26}$ If the legislature dislikes the results, it is always free to legislate again.

What this adds up to is, as Easterbrook puts it, a "relatively unimaginative, mechanical process of interpretation."27 Only this mechanical approach "can be reconciled with the premises of democratic governance."28 This approach is also consistent with the essence of the judicial function, which is to be governed by "the lines of the logical and analytical categories," operating under clear rules rather than fuzzy principles. ${ }^{29}$

22 Easterbrook, Text \& History, supra note 13, at 68.

${ }^{23}$ See Frank H. Easterbrook, Statutes' Domains, 50 U. CHI. L. REV. 533, 544-52 (1983).

24 Easterbrook, Text \& History, supra note 13, at 68 (footnote omitted).

25 See Note, Why Learned Hand Would Never Consult Legislative History Today, 105 HARV. L. REv. 1005, 1022 (1992).

${ }^{26}$ See United States v. Taylor, 487 U.S. 326, 345-46 (1988) (Scalia, J., concurring in part).

27 Easterbrook, Text \& History, supra note 13, at 67.

28 Easterbrook, Text \& History, supra note 13, at 63. As we will see in Part II, Easterbrook's description shortchanges the analytical sophistication of his own opinions; see also Marozsan v. United States, 852 F.2d 1469, 1498 (7th Cir. 1988) (en banc) (Easterbrook, J., dissenting) (criticizing the majority for being "too syllogistic, and the "life of the law has not been logic: it has been experience"" (quoting OLIVER WENDELl HOLMES, JR., THE COMMON LAW 1 (1881))); David L. Shapiro, Foreword: A Cave Drawing for the Ages, 112 HARV. L. REV. 1834, 1846-47 (1999) (remarking on the sophistication of Easterbrook's approach to statutory interpretation).

29 Antonin Scalia, Assorted Canards of Contemporary Legal Analysis, 40 CASE W. RES. L. REV. 581, 593 (1989/1990); see also Antonin Scalia, The Rule of Law as a Law of Rules, 56 U. CHI. L. ReV. $1175,1176-77$ (1989). 
Not surprisingly, the new textualism has been subject to a barrage of attacks by those who, like Posner, defend more pragmatic methods of statutory interpretation. ${ }^{30}$ These critics have attacked virtually every premise of textualist theory. Perhaps more significantly, even critics who sympathize with textualist goals attack the implementation of the formalist program by judges. They charge that courts have "begun to use textualist methods of construction that routinely allow them to attribute 'plain meaning' to statutory language that most observers would characterize as ambiguous or internally inconsistent;" and even to attribute plain meaning to language that "was nearly universally believed to have a contrary meaning for many decades."31 Others view the new textualism as increasing the tension between democracy and the rule of law, and as serving "as a cover for the injection of conservative values into statutes."32 In the name of greater candor about the role of policy judgments in statutory interpretation, these critics offer instead of textualism a pragmatic, dynamic approach to interpretation.

\section{B. Dynamic Interpretation/Pragmatism}

Several armies have seemingly gathered under the banner of pragmatism. $^{33}$ For our purposes, it may be enough to refer to Judge Posner, the leading judicial advocate of legal pragmatism. As a judge, Posner says he seeks to "strip away the conventional verbiage in which the issues come wrapped" and instead looks for "the actual interests at stake, the purposes of the participants, the policies behind the precedents, and the consequences of alternative decisions." ${ }^{34}$ Still, he says, the "social interest in certainty of legal obligation requires the judge to stick pretty close to statutory text and judicial precedent in most cases and thus to behave, much of the time anyway, as a formalist." 35

Yet, for Posner, conventional legal reasoning is only part of judicial decisionmaking. He views courts "at their best" as "councils of wise elders

${ }^{30}$ See, e.g., James J. Brudney, Congressional Commentary on Judicial Interpretations of Statutes: Idle Chatter or Telling Response?, 93 MICH. L. REV. 1, $40-66$ (1994); William N. Eskridge, Jr., Textıalism, the Unknown Ideal?, 96 MICH. L. REv. 1509, 1514-15 (1998); Martin H. Redish and Theodore T. Chung, Democratic Theory and the Legislative Process: Mourning the Death of Originalism in Statttory Interpretation, 68 TUL. L. REV. 803, 825-31 (1994); Lawrence M. Solan, Learning Our Limits: The Decline of Textualism in Statutory Cases, 1997 WIS. L. REv. 235, 237-38 (1997). For Posner's critique of textualism, see RICHARD A. POSNER, THE PROBLEMS OF JURISPRUDENCE 262-69 (1990). My own views can be found in Edward Adams \& Daniel A. Farber, Beyond the Formalism Debate: Expert Reasoning, Fuzzy Logic, and Complex Statutes, 52 VAND. L. REV. 1243 (1999).

31 Richard J. Pierce, Jr., The Supreme Court's New Hypertextualism: An Invitation to Cacophony and Incoherence in the Administrative State, 95 COLUM. L. REV. 749, 752 (1995).

32 William N. Eskridge, Jr., \& Philip P. Frickey, Foreword: Law as Eguilibrium, 108 HARv. L. REV. 26, 77 (1994).

${ }^{33}$ Useful recent commentary on legal pragmatism can be found in THE REVIVAL OF PRAGMATISM: New EsSays ON SOCIal ThOUght, LAW, AND CUlture 235-343 (Mortis Dickstein ed., 1998).

${ }^{34}$ POSNER, supra note 10, at 208-09 (paraphrasing a suggestion by Paul Freind as quoted by Mary Ann Glendon).

35 Id. at 209. 
meditating on real disputes," adding that "it is not completely insane to entrust them with responsibility for resolving these disputes in a way that will produce the best results in the circumstances rather than resolving them purely on the basis of rules created by other organs of government or by their own previous decisions. ${ }^{.36}$ The consequence, he cheerfully concedes, is that courts will sometimes treat the Constitution, and to a lesser extent statutes, "as a kind of putty that can be used to fill embarrassing holes in the legal and political framework of society."37 For example, a pragmatist judge would not stomach a sentence of life without parole to a sixteen-yearold who sold a single marijuana cigarette. ${ }^{38}$ All this, of course, is the worst form of heresy to formalists.

These pragmatist positions are not unfamiliar, and there is much to be said in their favor. Familiar arguments also exist against each of these positions (from formalists, in particular). What makes Posner's statement of these views seem, if not shocking, at least brutally candid is his expressed willingness on occasion to cut loose from conventional legal reasoning. Apropos of the marijuana cigarette case, for example, he says that if he found relevant evidence of original intent, he would "think it a valuable bone to toss to a positivist or formalist colleague," but he himself would put no weight on this evidence, not feeling himself "duty-bound to maintain consistency with past decisions. ${ }^{39}$

Pragmatism makes room for changing circumstances and changing conceptions of justice to mold the interpretation of statutes, making meaning dynamic rather than static. Bill Eskridge, the most prominent academic advocate for dynamic interpretation, argues that some degree of dynamism seems inherent in the enterprise of interpretation itself. At the most abstract level, Eskridge argues that all interpretation necessarily involves an effort to align the world of the reader with that of the author, making static interpretation impossible. ${ }^{40}$ Eskridge points out that dynamic interpretation is nothing novel in law. ${ }^{41}$ Finally, he maintains that the legal system cannot function effectively without some degree of dynamic interpretation. It is impractical to revise the entire United States Code every few years; inevitably, some provisions must be kept in place for decades if not longer. Intol-

37 Id. at 258.

38 See id.

39 Id. at 259.

40 See WILliam N. ESKRIDGE, JR., DYNAMIC STATUTORY INTERPRETATION 61-64 (1994). For a critique of Eskridge, see John C. Nagle, Newt Gingrich, Dynamic Statutory Interpreter, 143 U. PA. L. REV. 2209 (1995) (review essay).

41 He points out examples of dynamic interpretation in areas ranging from the law of contracts to the law of trusts. See ESKRIDGE, supra note 40, at 122-23. In other legal systems, some with highly formalist aspirations, dynamic interpretation of statutes is well accepted. See id. at $345 \mathrm{n} .2$. Moreover, even those most strongly opposed to dynamic interpretation utilize canons of interpretation that in practice provide a dynamic element. See id. at 118-19. 
erable anomalies would develop without some way to keep these provisions in tune with the changing times. ${ }^{42}$ Moreover, he argues, as the understandings of the law by those involved in its everyday administration evolve over time, abrupt efforts to restore the original understanding can undo justifiable patterns of reliance by the relevant actors.

The textualist response to all this is predictable but nonetheless powerful: it is up to the legislature and the executive to make policy judgments and adapt legal rules to changing times. It is up to unelected judges to follow the rules laid down for them.

As we have seen, both of our judges have been leading participants on opposing sides in this debate. Once they don their black robes, we might wonder, what do they do when confronted with a problem of statutory interpretation?

\section{BATTLES OF THE TITANS}

A Westlaw search found twenty-three cases through August 24, 1999 in which Posner and Easterbrook voted on opposing sides. ${ }^{43}$ Some were constitutional rather than statutory. With little pretension to social science rigor, I have selected four of the statutory cases for analysis because theories of statutory interpretation seem most salient in these cases. ${ }^{44}$

\section{A. Two Civil Actions}

Our first two cases involve what could be loosely considered commercial law (though one is a consumer transaction). The issues are not likely to strike most readers as intrinsically gripping, and in the hands of many judges, they might be dull as dust. Easterbrook and Posner, however, manage to find something more in them than dry technicalities.

1. The Case of the Fictitious Insurance: Adams v. Plaza Finance Co. ${ }^{45}$ We begin with the most recent of these decisions. It presented a classic case of whether to elevate form over substance. Some background is necessary, however, to understand the issue.

Adams was a class action brought under the Truth in Lending Act (TILA), the federal statute mandating consumer credit disclosures. ${ }^{46}$ The statute requires some loan expenses to be added into the annual percentage rate (APR) disclosed to the consumer, while other expenses can be added to the "amount financed," thereby lowering the apparent interest rate. One of the credit expenses that qualifies for the latter, more favorable treatment is

42 See id. at 48-49.

43 See Appendix B for search methods.

44 See Appendix A for summaries of the other cases.

45 168 F.3d 932 (7th Cir. 1999).

46 See 15 U.S.C. $\$ \S 1601-13,1631-41,1671-77$ (1994). For an enlightening discussion of the statute, its background and its failures, see Edward L. Rubin, Legislative Methodology: Some Lessons from the Truth-In-Lending Act, 80 GEO. L.J. 233 (1991). 
called nonfiling insurance. Such insurance protects the creditor against the risk that some clerical error or technical mistake will destroy the priority of its security interest. In Adams, the creditor was a company specializing in small, short-term loans to people with credit problems. It loaned Adams $\$ 307$ for 10 months at a hefty APR of $83 \%$. Of the $\$ 307, \$ 7$ was purportedly a fee for nonfiling insurance. If this fee were to be considered instead a part of the interest, the APR would go up to $89 \%$. On a smaller loan, the difference would be greater: for instance, on a $\$ 40$ loan with the same interest rate, the APR would shoot up from 80 to $109 \% .{ }^{47}$ The crucial question was whether the so-called filing insurance really qualified as such, so that it could be added to the amount financed.

The expense certainly had the form of a premium for nonfiling insurance. It was paid to a licensed insurance company pursuant to a written contract that on its face seemed to provide coverage for nonfiling risks. The insurer was licensed to sell nonfiling insurance in Illinois, where the transactions took place, and so far as the record shows, the Illinois insurance authorities had never found any reason to intervene. ${ }^{48}$

If the form of filing insurance was clearly present, the substance was not. The original contract expressly capped the insurance company's payout at ninety percent of the premiums, and an informal understanding to this effect allegedly remained even after the documents were rewritten. Thus, the so-called insured was guaranteed never to recover the full amount of its payments to the insurer. Moreover, the lender had little reason to want nonfiling insurance. Such insurance would have protected it from the loss of legal priority in its collateral, if seized by another creditor. But for this lender, this was an unlikely contingency. The collateral usually had negligible market value, and the insured did not bother filing its security interest anyway. Not surprisingly, when the lender did make insurance claims, the claims were generally not for nonfiling but instead for defaults when borrowers or their collateral could not be located. (Insurance for those defaults would normally be included in the APR.) So far as the record showed, the insurer had never-not once-paid a nonfiling claim on these contracts. ${ }^{49}$

This is not a case where the economic substance of a transaction is attenuated, but rather one where it has vanished completely, leaving the kind of complete vacuum that can normally be found only between galaxies. Yet the formalities of a nonfiling insurance contract were all present. In short, we have a textbook case of form versus substance. It will probably come as little shock to learn that Easterbrook, the formalist, opted for form over substance, while Posner stressed the economic realities of the transaction.

\footnotetext{
47 See Adams, 168 F.3d at 933, 935.

48 These are, not surprisingly, the facts on which Easterbrook relies. See id. at 937-38 (Easterbrook, J., dissenting).

49 See id. at $935-36$.
} 
Posner's position has the recommendation of common sense, which is undoubtedly why it was joined by the third judge on the panel. Posner shrewdly invokes our sense of the normal course of transactions. He asks us to imagine an insurance company that issues a policy to someone who does not drive or own a car and then pays claims that the insured submits for accidents caused by his bicycle. That is obviously bike insurance, not car insurance, no matter what the policy says. ${ }^{50}$ He also relies on common sense in response to the suggestion that, despite the ninety percent cap that prevents it from serving as a means of spreading risk, the policy might serve some more esoteric insurance function. At oral argument, he tells us, the lender's lawyer was able to identify only one possible function for the policy "and that is to avoid having to include seven dollars in the finance charge." comes the clincher: "If the only function of the insurance policy is to monkey with the disclosed interest rate, it is not a bona fide policy; it is a fraud." ${ }^{92}$

For a formalist, however, perhaps the conclusion is not so obvious. Although Easterbrook's position is no surprise, how he gets there is more interesting. One might have expected a frontal attack on the whole concept of placing substance over form. A formalist might well regard this doctrine as nothing but an invitation to creative judicial rewriting of transactions, producing uncertainty and inviting results-based decisions. As one might expect, Easterbrook does stress the uncertainty created by the decision, noting that ultimately litigation costs will be passed on to the borrowers that the statute is intended to protect. But Easterbrook's argument is more subtle. Essentially, he argues that the "form over substance" issue can find no foothold in this case because of the nature of TILA. The substance of the transaction relates to the amount of money the consumer ends up paying, over what period of time, but these details are fully disclosed. The plaintiff's claim relates solely to the form of the disclosure-the seven dollars was allegedly entered under the wrong heading. But the headings themselves are arbitrary: nonfiling insurance premiums are excluded from the APR only by legislative fiat. Thus, Easterbrook argues, there is no substance here, only form. In addition, he contends, the Federal Reserve has the power to plug loopholes with new regulations, and this authority provides a far better mechanism because it gives advance notice to lenders, who may face draconian penalties under the statute if a court later decides some expense was misclassified in the disclosure statement. ${ }^{53}$

Easterbrook shows Adams to be a harder case than it initially appears. But the counterarguments are not inconsiderable. The phony filing insurance is not only an evasion of the statute, and a transparent one at that, but is also clearly injurious to the class of consumers that the statute is intended

${ }^{50}$ See id. at 936.

51 Id. at 934.

52 Id. at 935.

53 See id. at $936-39$. 
to protect. Recall that the lender loses money on the policies because total claims are capped at ninety percent of the premiums paid, guaranteeing at least a ten percent loss to the lender on the insurance transaction itself. This would be senseless unless the deception allowed it to raise interest rates or attract additional new customers. Moreover, the Federal Reserve presumably has better things to do with its time than to rewrite its regulations every time a few lenders devise an ingenious shady practice.

Still, although Easterbrook's argument may not ultimately persuade, it is much more pragmatic than one might have expected: not an argument for "formalities über alles," but a context-based functional analysis of why reliance on form is appropriate in this specific setting. His analysis does not quite fit his own description of formalism as a "relatively unimaginative, mechanical process of interpretation."

2. The Limited Hegemony of the Text: Wisconsin Knife Works v. National Metal Crafters. ${ }^{54}$ Our other commercial case involves the Uniform Commercial Code (U.C.C.). The issue was the effect of a "no oral modifications" (NOM) clause. ${ }^{55}$ Before leaping into the facts of the case, some background is again helpful. It is not uncommon for one party to agree orally to allow the other party to contract to change its performance. At common law, the modification would be invalid if it lacked any consideration, but otherwise it would be enforceable. A NOM clause was impotent because the parties could always orally modify the NOM clause itself, on the theory that they could not deprive themselves of the power to enter into new contracts. ${ }^{56}$

Section 2-209 of the U.C.C. revised these common law rules. Subsection 1 eliminates the requirement of consideration for modifications. (Official Comment 2, however, reminds us that good faith is required, as it is under all Code transactions.) Subsection 2 validates NOM clauses. Subsection 3 addresses the Statute of Frauds, which was not at issue in Wisconsin Knife..$^{57}$

54781 F.2d 1280 (7th Cir. 1986).

55 For a clear overview of this issue, see CLAYTON P. GILLETTE \& STEVEN D. WALT, SALES LAW: DOMESTIC AND INTERNATIONAL 75-82 (1999). Gillette and Walt suggest that as a policy matter, the question should be whether a course of performance under a contract provides the same kind of evidentiary security as a written modification, thereby satisfying the evidentiary concerns behind the NOM clause. See id. at 81-82. This is an important consideration, but perhaps not the only one. It is also important to take into account the possibility for opportunism created by NOM clauses, particularly since the opposing party may not actually have assented to the clause in a "battle of the forms" situation and may be surprised to leam that it is part of the contract. The pre-Code history and the evolution of the U.C.C. treatment of the issue are analyzed in John E. Murray, Jr., The Modification Mystery: Section 2209 of the Uniform Commercial Code, 32 VILL. L. REV. I (1987). For a more recent treatment of the issue, see David V. Snyder, The Law of Contract and the Concept of Change: Public and Private Attempts to Regulate Modification, Waiver, and Estoppel, 1999 WIS. L. REV. 607, 638-49.

${ }^{56}$ This may seem formalistic, but we would probably accept such a theory in the analogous public law context. For instance, Congress could not pass an ordinary law (as opposed to a constitutional amendment) that deprived it of the power to enact future legislation on certain topics.

57 Since there was no Statute of Frauds issue in Wisconsin Knife, I will ignore the Statute of Frauds throughout this discussion. 
This brings us to the two subsections involved in Wisconsin Knife. Both of them bear on the effect of an attempted modification that is blocked by a NOM clause, and both have something to say about "waivers." Subsection 4 brings the waiver concept into play. It states that "[a]lthough an attempt at modification or rescission does not satisfy the requirements of subsection 2 or 3 it can operate as a waiver.",58 Subsection 5 tells us what happens in certain circumstances if the waiving party has second thoughts:

A party who has made a waiver affecting an executory portion of the contract may retract the waiver by reasonable notification received by the other party that strict performance will be required of any term waived, unless the retraction would be unjust in view of a material change of position in reliance on the waiver. ${ }^{59}$

Wisconsin Knife involved a somewhat complicated set of dealings. On the assumption that many readers will have little interest in the details of commercial transactions, let me offer an equivalent hypothetical instead. ${ }^{60}$ Suppose that $B$ orders two truckloads of orange widgets from $S$, one to be shipped in June and the other in August. It turns out that $S$ failed to manufacture enough orange widgets to fill the June order. $B$ somewhat prefers orange widgets, but values its continuing relationship with $S$. In May, $B$ and $S$ agree orally and in good faith to substitute green widgets that $S$ has in stock. ${ }^{61}$ A NOM clause prevents the oral agreement from taking effect as a modification of the contract (so that $S$ would be on safe ground in shipping orange widgets, if it managed to obtain them). $S$ ships green widgets in June. After receiving those widgets, $B$ informs $S$ that it intends to insist on its right under the original contract to orange widgets. As law professors are apt to ask in exam questions, "What are the rights and liabilities of the parties?"

The status of the August order seems clear. It seems plain from subsection 5 that, unless $S$ has relied to its detriment in its widget manufactur-

58 U.C.C. $\$ 2-209$ (4) (1999). The drafters do not, unfortunately, explain the nature of the "it" that acts as a waiver (and whether it always does so, or only sometimes), how "operating as a waiver" is different than simply being a waiver, or what "waiver" (a notoriously slippery concept) means in this context.

59 U.C.C. \& 2-209(5) (1999).

${ }^{60}$ For those who are interested, here is a somewhat simplified version of the actual facts. After some preliminary negotiations, the buyer sent the seller a series of purchase forms for metal blanks that included an NOM clause. The parties then set delivery dates for the first two purchase orders, which became part of the contract. The seller then missed the deadline, but rather than taking any action, the buyer chose to continue the contract. The jury found that the parties had agreed to a modification of the delivery dates. Although it had fallen more than a year behind, the seller continued manufacturing the blanks. Perhaps opportunistically, the buyer then notified the seller that the contract was being terminated. The buyer then filed suit for the late deliveries. The question before the court was whether the buyer's various interactions with the seller had waived its right to sue for violation of the original delivery date. More specifically, in order to establish a waiver, would the seller have to show that it relied on the oral modification to its detriment? See Wisconsin Knife, 781 F.2d at 1283-84.

${ }^{61}$ There is no consideration for this modification, but recall that this is unnecessary under U.C.C. \& 2-209(1), so long as the parties were operating in good faith. 
ing on the oral order for green widgets, $B$ is entitled to insist on the orange widgets for August and to sue for damages if it gets green ones instead. That part of the contract is still executory and therefore the waiver can be retracted absent reliance. But what about the June order? $S$ cannot claim to have relied on the modification; it could not have shipped orange widgets in June anyway because it had failed to make enough of them. ${ }^{62}$ But after agreeing to the change in good faith, it seems harsh to allow $B$ to sue for damages because of the color of the June widgets. ${ }^{63}$

The effect of ruling for $S$ in this situation (finding an effective waiver for June) is to weaken the effect of NOM clauses and thereby open written contracts to the uncertainties of claimed oral modifications. This looks analogous to allowing statutes to be modified through legislative history, and one might have expected a formalist like Easterbrook to bridle at the notion of undermining the authority of the text of the contract. With both statutes and contracts, departing from the written text arguably undermines certainty, encourages sloppy drafting, and provides more room for resultoriented decisions. ${ }^{64}$ But despite these arguable similarities, Easterbrook takes a firm position in favor of oral modifications, contending that reliance is not necessary to an effective waiver. ${ }^{65}$ Though he presents the argument more carefully and at somewhat greater length, it is fundamentally quite simple (and also, quite consistent with his version of formalism). ${ }^{66}$ Subsection 5 tells us that a waiver can be retracted as to the executory portions of the contract (the August widgets) unless there has been reliance. Subsection 4 tells us that unless subsection 5 applies, the waiver is effective, meaning that the buyer cannot sue over the color of the June widgets (and cannot object to getting green widgets in August if the seller has relied). ${ }^{67}$

Posner, writing for the majority, takes the opposing view of contract modifications. He seems to ignore the overriding purpose of the section as stated in official comment 1: "to protect and make effective all necessary and

62 This example is somewhat artificial because it assumes away reliance as to the June order, whereas in a real case such as Wisconsin Knife reliance will usually involve an issue of fact. But the example does have the advantage of highlighting exactly where the reliance question enters the case.

${ }^{63}$ It is also possible that if the June delivery is a breach, $B$ might be entitled to cancel the contract under U.C.C. \& 2-612(3), but on the facts given, the breach probably would not be considered to impair the value of the contract as a whole. (In addition, note that even if otherwise entitled to cancel, $B$ waives its right to cancel if it accepts the shipment without "seasonable" notification of cancellation; § 2-612(3) says nothing about reliance as a factor in the effectiveness of this waiver.)

${ }^{64}$ On the link between textualism in statutory interpretation and contract law, see Stephen F. Ross \& Daniel Tranen, The Modern Parol Evidence Rule and Its Implications for New Textualist Statutory Interpretation, 87 GEO. L.J. 195, 198-99, 221-42 (1998).

${ }^{65}$ See Wisconsin Knife, 781 F.2d at 1291-92.

${ }^{66}$ See id. at $1290-94$.

67 See id. at 1290-92 (Easterbrook, J., dissenting). Easterbrook may also have had in mind a policy argument. He said in another case that parol evidence usually "facilitates flexible arrangements" that are beneficial in relational contracts. Bidlack v. Wheelabrator Corp., 993 F.2d 603, 618 (7th Cir. 1993) (en banc) (Easterbrook, J., dissenting). 
desirable modifications of sales contracts without regard to the technicalities which at present hamper such adjustments." ${ }^{, 68}$ Instead, Posner emphasizes the usefulness of NOM clauses. The crux of his argument is that a contrary holding would take away the effectiveness that subsection 2 purports to confer on NOM clauses. "Whether called modification or waiver," what the seller was "seeking to do is to nullify a key term other than by a signed writing"; allowing this would make subsection 2 "very nearly a dead letter."69

Although Posner's argument relies mostly on statutory purpose, he also makes an effort to come to terms with the text of 2-209. For Posner, the critical language is the phrase, "can operate as a waiver," in subsection 4. Posner reads this clause to mean something like "operates as a waiver provided there is reliance." This interpretation seems to make subsection 5 incongruous, since that subsection seemingly assumes that some waivers do take effect without reliance. Posner deals with the incongruity by arguing that subsection 5 is directed at issues other than oral modification, the subject of the rest of the section. ${ }^{70}$

In favor of this reading of section 2-209, Posner argues that the Code approved of NOM clauses as a substitute for the evidentiary and cautionary functions of consideration, given the elimination of that requirement in subsection 1. Reliance, but not a purely oral modification, can serve some of the same functions as consideration."

According to Easterbrook, the parties did not even mention the reliance issue in their briefs. ${ }^{72}$ Perhaps a fuller briefing would have been of some assistance to the majority. In any event, Posner's linkage between NOM clauses and consideration seems strained: NOM clauses have generally been thought to be more like private statutes of frauds than like a substitute for consideration. Posner's reading of subsection 5 as a stand-alone provision extending beyond oral modifications also seems like a stretch. As Easterbrook concedes, "repair work" on statutes is sometimes necessary because the complexities of the legislative process may produce slapdash, internally inconsistent work. But as he goes on to say, this is hardly true of the U.C.C., which was "one of the most carefully assembled statutes in American history."73

The drafting of section 2-209 is less than perfect, so it is impossible to be completely confident about the section's meaning. ${ }^{74}$ The statute says

68 U.C.C. $\$ 2-209$, Comment 1 (1999). In a like vein, one of the comments to the preceding section on course of performance speaks of the need "to preserve the flexible character of commercial contracts and to prevent surprise or other hardship." U.C.C. $\$ 2-208$, Comment 3 (1999).

69 Wisconsin Knife, 781 F.2d at 1286.

70 See id. at 1287.

71 See id. at 1285-86.

72 See id. at 1290 (Easterbrook, J., dissenting).

73 Id. at 1291 (Easterbrook, J., dissenting).

74 See, e.g., Douglas K. Newell, Cleaning Up U.C.C. Section 2-209, 27 IDAHO L. REV. 487, 493 (1990/1991) (calling the section a "drafting nightmare"). Perhaps the only weakness of Easterbrook's 
that an oral modification "can operate as a waiver," so Posner's view (that reliance is also needed) is not squarely inconsistent with plain language. In the end, though, Easterbrook seems to attribute a more plausible meaning to section 2-209 as a whole. ${ }^{75}$ Posner's reading of subsection 5 seems particularly strained. But Posner could be right on larger policy grounds, if we think that NOM clauses ought to be more fully enforced so as to allow the parties to establish a firm written framework for their transaction. ${ }^{76}$ For the sake of argument, assume that this policy view is correct, and also suppose that it is a strained (though not impossible) reading of the current text of the U.C.C. Should a judge read this meaning into the text anyway? ${ }^{77}$ The answer depends on whether we take the U.C.C. to be a true code, establishing the definitive framework for transactions within its scope, or whether we consider it to be something like a statutory version of a Restatement, consolidating the best of existing legal thought but not foreclosing further common law development. ${ }^{78}$ Assuming he is right on the policy question, Posner's position could be defended as a somewhat aggressive common law development under the statute. Posner does not, however, attempt a defense of this nature.

\section{B. Drug Wars}

Readers familiar with the more exciting world of public law, and who found the commercial law cases a strain on their attention, should have an easier time with the next two cases. In their own way, they too are commercial cases (about merchants, even), but the trade in question is that of drug dealing.

1. Of Pawns and Kingpins: United States v. Pino-Perez. ${ }^{79}$ After the complexities of the U.C.C., Pino-Perez provides a refreshing contrast. A federal statute imposes draconian penalties on "kingpins" who manage

opinion is that he makes the text seem simpler and clearer than it really is, but this may be a reasonable thetorical ploy, particularly for a dissenter.

75 There seems to be a consensus in favor of Easterbrook's reading of the current statute, rejecting Posner's interpretation. See GILLETTE \& WALT, supra note 55, at 81.

${ }^{76}$ Notably, a recently proposed revision of the U.C.C. adopted Posner's view. See National Conference of Commissioners on Uniform State Laws, Revision of Uniform Commercial Code Article 2-Sales, \$ 2-209 (March 1, 1999) <http://www.law.upenn.edu/library/ulc/ucc2/ucc2399.ext>.

77 Where the text of the U.C.C. is completely clear or completely ambiguous, the question of whether to resort to policy seems easier.

78 Both Easterbrook and Posner could agree, I believe, with the statement in the text about common law development, though Easterbrook would resolve it by asking whether the statute itself mandates common law elaboration; cf. Frank Easterbrook, The Case of the Speluncean Explorers: Revisited, 112 HARV. L. REV. 1913 (1999) (arguing in favor of implying a defense of necessity despite the seemingly absolute terms of a criminal statute, based on historical role of courts in evolving criminal law doctrine). In contrast, Posner might ask whether a common law approach was better policy.

79870 F.2d 1230 (7th Cir. 1989) (en banc). For a perceptive commentary on the case, see Sharon C. Lynch, Comment, Drug Kingpins and Their Helpers: Accomplice Liability Under 21 U.S.C. Section 848,58 U. CHI. L. REV. 391 (1991). 
drug-dealing organizations. ${ }^{80}$ Under section 2 of the federal criminal code, anyone who aids and abets a federal crime can be punished as if they themselves had committed that crime. ${ }^{81}$ Logically, section 2 means that people who merely assist a kingpin can be punished as if they themselves were kingpins. But this seems to make no sense, because it would mean that everyone connected with drug rings receives the same high punishment, which completely nullifies Congress's apparent desire to impose higher punishment on the managers.

Plainly, Congress could not have intended to punish all participants equally, or it would not have singled out managers. For this reason, the government conceded that the kingpin's employees could not be punished as aiders and abetters. ${ }^{82}$ It did argue, however, that independent contractors were subject to aiding and abetting liability. (Of course, these people might turn out themselves to be serious violators of the drug laws, even if they were not technically kingpins. Pino-Perez himself was a major wholesaler. Although he was a much bigger player than the so-called kingpin whom he allegedly assisted, apparently the government was unable to show that he met the statutory definition. ${ }^{83}$ ) But the government's interpretation also seems a bit paradoxical, since it exempts employees but punishes independent contractors even though the employees are the ones most clearly aiding and abetting the kingpin. Because of these incongruities, in a case preceding Pino-Perez, the Second Circuit rejected the government's position and held that independent contractors cannot be punished as aiders and abetters. ${ }^{84}$

Pino-Perez seems a perfect test case for theories of statutory interpretation. The text of section 2 is perfectly clear in applying aider and abetter liability to all federal crimes, but the result seems a bit senseless. Who could devise a better case for the formalist Easterbrook to proclaim the necessity of textual fidelity or Posner to decry senseless formalism? But the reader who is expecting these theoretical fireworks will be disappointed, if not startled. It is Posner who comes out for a literal reading of the text, while Easterbrook calls for pragmatic good sense!

The key difference between the two judges' opinions consists in their treatment of previous cases that found exceptions to aider and abetter liability. It is clear, for example, that a drug dealer's customers cannot be found guilty of aiding and abetting the sale, though it obviously could not take place without them. Posner classifies the exceptions from liability into three overlap-

${ }^{80}$ See 21 U.S.C. $\$ 848$ (1994). More precisely, the statutes impose a severe mandatory sentence on anyone convicted of engaging in a "continuing criminal enterprise" (CCE). A person commits this CCE offense if he "occupies a position of organizer, a supervisory position, or any other position of management" over at least five people who commit in concert a continuing series of felony drug crimes. Id.

${ }^{81}$ See 18 U.S.C. \& 2(a) (1994).

82 See Pino-Perez, 870 F.2d at 1230 (citing United States v. Ambrose, 740 F.2d 505, 507-08 (7th Cir. 1984); United States v. Amen, 831 F.2d 373, 381-82 (2d Cir. 1987)).

${ }^{83}$ See Pino-Perez, 870 F.2d at 1232.

84 See Amen, 831 F.2d at 382. 
ping categories: (1) people whose participation is part of the definition of the principal's crime (like the kingpin's employees); (2) victims of the crime (even if they are willing victims, like the drug buyer); and (3) people who are part of the group that the law is designed to protect (such as the minor in a statutory rape case) ${ }^{85}$ He then declines to create a new exception excluding the kingpin statute from aider and abetter liability. To do so, he argues, "would introduce great uncertainty into federal criminal law if the liability of a conceded aider and abetter depended on the results of an inquiry into Congress's intent" in creating the substantive offense. ${ }^{86}$

Posner rejects the argument that this reading of the statute would impose draconian sentences on individuals who assisted the kingpin in minor ways, for two reasons. First, many of those individuals might not technically be aiders and abetters. ${ }^{87}$ Second, "in no reported case has the participation of the aider and abettor been so meager relative to the kingpin's that subjecting him to the minimum penalty in the kingpin statute would be savage or incongruous." 88 Thus, he ultimately supports a highly formalist result on pragmatic grounds.

Easterbrook the textualist begins his analysis by arguing that "statutory texts cannot dispose of the case." ${ }^{.89}$ The employee exception, with which everyone agrees, is non-textual. Also, making a drug supplier such as PinoPerez an aider and abetter would make his sentence independent of the amount he sold, contrary to Congress's sentencing scheme for dealers. ${ }^{90}$ It would also create a "crazy-quilt pattern of liability" in which assistants outside the organization would receive much stiffer sentences than more important henchmen inside the organization." ${ }^{91}$ Still, he says, "[i]f \& 2(a) traditionally were read woodenly, that would be that," for the kingpin statute "must be understood against the interpretation $\S 2(a)$ had when Congress acted." $"$ But he views the existing exceptions as embodying a general principle that the scope of aider and abetter liability "depends on the structure and functions of the substantive statute." 93

${ }^{85}$ See Pino-Perez, 870 F.2d at 1231-32 (citing United States v. Southard, 700 F.2d 1, 19-20 (1st Cir. 1983)).

86 Id. at 1234.

87 See id. at 1235. Not everyone whose actions assist the criminal is an aider and abetter. For example, a store that sells an address book to a call girl is not abetting the crime of prostitution, even if the sales clerk knows of her occupation. See United States v. Blankenship, 970 F.2d 283, 286 (7th Cir. 1992). In Blankenship, Judge Easterbrook sets out a functional test: "whether the imposition of liability on transactions of the class depicted by the case would deter crime without adding unduly to the costs of legitimate transactions." Id. at 287.

${ }^{88}$ Pino-Perez, 870 F.2d at 1237.

${ }^{89}$ Id. at 1238 (Easterbrook, J., dissenting).

${ }^{90}$ See id.

91 Id.

92 Id. at 1239.

${ }^{93} \mathrm{Id}$. 
As to how far to depart from literalism, Easterbrook adds, "the legislative history is suggestive." The legislative history showed that the kingpin statute began as a sentence enhancement (in which form it would not have triggered liability for aiders and abetters). It was transformed into a substantive offense only because of due process concerns. ${ }^{95}$ Summarizing the legislative history, he says:

Once we enter the business of reading the structure and functions of $\S$ 848 [the kingpin statute], how $\S 848$ came to its current form and how aiding and abetting liability undercuts the limitations of $\S 841$ [covering large-scale dealers] become important. The debates show Congress in a savage mood, no doubt, but its wrath had a specific object. The concern of the legislature lay in its desire to create mandatory minimum (and life maximum) penalties for the doyens of drugs, not in achieving increases in the sentences of aides-de-camp. ${ }^{96}$

Easterbrook does not provide much of an explanation of why it is permissible to resort to the legislative history here, a move he usually disfavors, but there are a couple of hints: he finds the legislative history only "suggestive," not binding, and he has already decided for other reasons that the text itself cannot resolve the case.

The fact that the alignment of the two judges in this case seems initially surprising is not evidence of inconsistency. The two judges' theories of statutory interpretation are sufficiently subtle to preclude any mandate for either "literalist readings" by one or "pragmatic results" by the other. Posner has plausible pragmatic reasons for adopting what is ultimately a literal interpretation of the statute. Easterbrook provides sensible formalist reasons for departing from a literal reading of section 2, based on its interpretation at the time the new drug laws were adopted and on the tension between a literal reading of section 2 and the apparent meaning of the newer laws. (In effect, Easterbrook seems to be arguing for a limited implied repeal of section 2 by section 848 .) He also hints at the end of his opinion at another formalist concern when he says that the "prosecutor must find a statute that is applicable, and the interplay among provisions helps us to know a statute's domain." ${ }^{.97}$ As his early scholarship shows, the desire to keep statutes within their bounds of application, rather than allowing them to expand common-law fashion, is an important part of his formalism.98

Thus, neither Posner nor Easterbrook can be accused of infidelity to their respective theories of interpretation in Pino-Perez. But it would not be hard to imagine other judges applying those theories with the opposite results.

95 See id. at $1239-40$.

96 Id. at 1240 (citations omitted).

${ }^{97}$ Id. at 1241.

98 See Easterbrook, supra note 23. 
2. The Stained Blotter of the Law: United States v. Marshall. ${ }^{99}$ I have deliberately saved the best case for last. Marshall, another apparently routine drug case, contains a wonderful discussion of legal theory. The legal issue is easily explained. A federal statute sets a five year mandatory sentence for anyone who sells more than one gram of a "mixture . . . containing a detectable amount" of LSD. ${ }^{100}$ (It also sets higher mandatory sentences for sales of larger weights, and the sentencing guidelines at the time also made weight a factor. ${ }^{101}$ ) The reference to mixtures was added to this subsection, as well as to subsections dealing with most other drugs, when Congress established sentences for various drugs. Congress apparently had in mind the practice of cutting drugs by street dealers of cocaine and heroin and wanted to impose heavy sentences on major retailers as well as wholesalers. But LSD itself weighs almost nothing. Consumers buy it in combination with a carrier, most commonly blotting paper. Because it is sold by the dose, the weight has no relevance to the transaction. The government claims, however, that the LSD/blotting paper combination counts as a "mixture" of LSD and paper. (This is apparently correct from a chemist's point of view, since the two are intermixed but not chemically bonded.) The effect of the government's theory is that the seller's sentence may depend largely on the weight of the medium he chooses. Thus, 19,999 pure doses of LSD weigh less than a gram and would escape the statutory minimum; a single dose sold on a sugar cube would carry a mandatory five-year sentence. Essentially, this is the only relevant information disclosed by the opinions. The question is what to make of it. ${ }^{102}$

In Marshall, unlike Pino-Perez, Posner and Easterbrook line up as one might expect, with the formalist (writing for the majority) applying the statutory language literally, and the pragmatist protesting against the wantonly arbitrary imposition of such harsh punishment. ${ }^{103}$ Putting aside some ancillary issues about some postenactment statements by legislators and about constitutional issues that might affect the outcome, each side's position is quite simple. Easterbrook says that it simply is not possible to construe the statute to apply only to the net weight of the drugs. ${ }^{104} \mathrm{He}$ also argues that in practice sentencing under the provision will not be as arbitrary as the dissent predicts, nor as different from sentencing for sales of other drugs. ${ }^{105}$ Posner

99908 F.2d 1312 (7th Cir. 1990), aff'd sub nom., Chapman v. United States, 500 U.S. 453 (1991).

10021 U.S.C. $\$ 841$ (b) (1994).

101 See id. at 1315.

${ }^{102}$ Chief Justice Rehnquist's businesslike opinion in Chapman lays out all of this information succinctly.

103 Unlike in Pino-Perez, Easterbrook finds no significant inconsistency with other provisions and no past history of interpretative flexibility, while Posner finds the kind of arbitrary harshness he thought lacking in Pino-Perez. Neither is being inconsistent, despite the superficial tension between the cases.

104 See Marshall, 908 F.2d at 1317.

105 See id. at 1316-17. He also suggests that sellers who are stupid enough to use heavy carriers deserve their fates. See id. at 1325 . Prospectively, the statute should have little effect: presumably any dealer who is not a complete idiot will choose the lightest carrier possible. 
thinks this sentencing standard makes no more sense than "basing the punishment for selling cocaine on the combined weight of the cocaine and of the vehicle (plane, boat, automobile, or whatever) used to transport it or the syringe used to inject it or the pipe used to smoke it."106 Posner notes that neither the legislative history nor the Justice Department provides any clue into why Congress would want such a bizarre sentencing scheme for LSD, and he speculates that Congress probably had no idea how LSD is sold. ${ }^{107}$

Before considering any larger jurisprudential issue, it is worth examining the textual question more closely. The LSD section does refer specifically to mixtures. Easterbrook is apparently right that a chemist would consider the LSD/paper combination to be a mixture. But it is not clear that this should be decisive. If instead of using blotting paper, dealers were able to imprison the LSD between sheets of some film, this would not constitute a mixture (no "mixing") but this difference seems irrelevant to sentencing. No ordinary speaker of English would call a stained piece of blotting paper a paper/stain mixture, any more than we would call a wet shirt a cotton/water mixture. ${ }^{108}$ Thus, the meaning of the term "mixture" is by no means as clear as Easterbrook suggests, and in fact the courts have had considerable difficulty with it in connection with other drugs. ${ }^{109}$ But Easterbrook does have one major point on his side: no one has a plausible example of anything else that might qualify as a "mixture" of LSD for sentencing purposes. ${ }^{110}$ Either the term is a virtual nullity or it means what Easterbrook says. Posner is essentially willing to nullify the term because he thinks it renders crazy an otherwise sensible statutory provision. ${ }^{111}$ Easterbrook thinks that applying the term is at least a bit less crazy (mostly because the extreme hypotheticals are unlikely to arise in practice, ${ }^{112}$ also because of the effect of other drug sentencing laws), and he is unwilling to rewrite the statute.

By reading the statute literally rather than essentially wiping out the reference to mixtures, Easterbrook is taking the legal path of least resistance, and he feels little need for jurisprudential discussion. Posner, however, is advocating a less traveled path, and is correspondingly in need of philosophical support. He sees the deeper issue as whether "the content of law is exhausted in clear, explicit, and definite enactments by or under express delegation from legislatures," or whether judges have authority "to enrich positive law with the moral values and practical concerns of civilized society." Both approaches have their prices: "The first buys political

106 Id. at 1332 (Posner, J., dissenting).

107 See id. at 1333 (Posner, J., dissenting.).

108 See ESKRIDGE \& FRICKEY, supra note 2, at 588-89.

109 The cases are summarized in Todd E. Gonyer, Comment, Federal Sentencing in a Post-Chapman World: What Is a "Mixture or Substance" Anyhow?, 46 U. KAN. L. REv. 983 (1998).

110 See Marshall, 908 F.2d at 1317-18, 1319.

111 See id. at 1334.

112 See id. at 1324-25.

${ }^{113}$ Id. at 1335 (Posner, J., dissenting). 
neutrality and a type of objectivity at the price of substantive injustice, while the second buys justice in the individual case at the price of considerable uncertainty and, not infrequently, judicial willfulness."114 In Marshall, he says, the equitable approach is more appealing. Posner concludes that the statute should be interpreted against our society's background norm of equal treatment, to avoid making "Congress's handiwork an embarrassment to the members of Congress and to us."115

Marshall is a very difficult case. Perhaps it is enough to say that Easterbrook and Posner both make excellent arguments-much better than those made in the Supreme Court on appeal-and to leave it at that. But it seems unfair to escape without saying something about my own view of the case. Easterbrook argues persuasively that the inequities produced by the government's approach are less severe than the parade of horribles would indicate, but they still seem substantial. (Consider, by way of comparison, a statute that made the sentence for child molestation vary inversely with the child's weight; this would often - but not always-produce reasonable results since weight correlates with age. But since age is easily determined, it seems gratuitously arbitrary to use weight as the sentencing standard instead.) But I am troubled by a reading of the statute which has the practical effect of nullifying one of its terms, even if the term conceivably may have been included only by mistake. So I find the arguments quite evenly balanced. Because the case is so close, the idea of "remanding" to the legislature seems attractive. If the court rules in favor of the government, as a practical political reality there is no chance that Congress would ever reconsider the issue, for doing so would risk being seen as soft on drugs. ${ }^{116}$ But if the court rules for the defendant, the Justice Department will surely succeed in getting the issue put on the congressional agenda, giving Congress the opportunity to clarify the statute. Or, in other words, this may be a perfect case in which to apply the "rule of lenity." 117 On that basis, then, I would be inclined to side with Posner.

\section{DOES THEORY MATTER?}

Of the cases we have discussed, Marshall seems most closely tied to the split between formalism and pragmatism. Yet even in Marshall, the linkage is weaker than it may appear. The government actually has some plausible pragmatist arguments along the following lines: the statute may not produce huge inequities in practice, allowing courts in effect to erase statutory language would create major legal uncertainties, and in any event

114 Id.

115 Id. at 1338 (Posner, J., dissenting).

116 For empirical evidence to this effect, see William N. Eskridge, Jr., Overriding Supreme Court Statutory Interpretation Decisions, 101 YALE L.J. 331, 361-62 (1991).

117 On this rule, see Lawrence M. Solan, Law, Language, and Lenity, 40 WM. \& MARY L. REV. 57 (1998). 
the defendants are the kind of large-scale commercial dealers that Congress wants to punish, putting aside the technicalities. The formalist argument on the other side is even simpler. Congress is made up of ordinary people, not chemists, and to the ordinary person, the LSD/paper combination is not a "mixture." If the result of giving the term its ordinary meaning is to render it nugatory, that's just too bad; it is not the court's job to ensure that every word in a statute actually accomplishes something practical. So, even in Marshall, it is not clear that the results are determined by theory.

Apart from Marshall, Adams (the TILA case) seems to turn most on the formalism question. But again the linkage is weaker than it appears. Given that TIIA seems to have produced very little public benefit, ${ }^{118}$ a pragmatist might just think it better to lower compliance costs by narrowly construing the statute. In contrast, a formalist might say that no ordinary observer would consider the lender's payment to be an actual expenditure for filing insurance, even though the appropriate words appear in the document-just as no ordinary person would think that the word "grapefruit" applied to a Styrofoam ball with a fruit peel glued on the surface.

Thus, our case studies do not establish any strong connection between theory and outcome. (They also show that pragmatist arguments can support apparently formalistic results, and vice versa.) But of course, these are only four cases out of all those on which Easterbrook and Posner have sat. What about the statistical picture? ${ }^{119}$

Since 1985, the Seventh Circuit has heard about fifteen thousand cases, of which $4.5 \%$ have dissenting opinions. ${ }^{120}$ (Apparently, federal appellate courts hear many thousands of "easy" cases in which there is little ground for disagreement. So much for "legal indeterminacy"!) Assume all judges are equally prone to dissent, regardless of the panel composition. If we limit our attention to cases in which any two judges, $\mathrm{X}$ and $\mathrm{Y}$, are sitting, we should still find a $4.5 \%$ rate of dissenting opinions. But in one-third of the split decisions, it would be the third judge who is in dissent, with $X$ and $\mathrm{Y}$ in the majority. So $\mathrm{X}$ and $\mathrm{Y}$ would be on the opposite of two-thirds of $4.5 \%$ of the cases, or $3 \%$. I found 23 cases in which either Posner or Easterbrook was in the majority and the other in dissent, out of 867 cases heard by both. This comes to $2.7 \%$, slightly below what one would expect

118 See Rubin, supra note 46, at 235-39.

119 See Appendix B for exact figures and the search terms used to derive these statistics.

120 A Westlaw query ran in August 1999 yielded 15,170 total cases and 677 cases with dissenting opinions. The searches were conducted in the database for the Seventh Circuit that contains decisions and orders. To see if the Seventh Circuit is unusual, the same searches were conducted in the database for all Circuit Courts of Appeals. Of a total of 316,010 cases, 9,679, or $3 \%$, contain dissenting opinions. Thus the Seventh Circuit may be slightly above average in this regard. (However, the denominators may not be precisely comparable. Unlike the Seventh Circuit, opinions in other circuits are less likely to have a syllabus ( $56 \%$ versus $89 \%)$. This may reflect some difference in reporting practices that could affect results.) 
of any two randomly selected judges. ${ }^{121}$ These statistics seem to show that Posner and Easterbrook's starkly conflicting jurisprudential views do not lead to any great disparity in their votes. Perhaps even more strikingly, both of them seem to agree with the remaining third judge in more than $95 \%$ of the cases.

These figures do not quite prove that the jurisprudential differences are irrelevant to voting. Posner and Easterbrook have in some other respects more in common than two randomly selected judges: they are both white males, conservatives, ${ }^{122}$ former tenured members of the University of Chicago faculty, believers in law-and-economics, appointed to the bench by the same president, and so forth. These similarities might lead them to vote together more often than two randomly selected judges. If so, jurisprudential differences might be driving them apart again. The fact that their similarity exactly counters their other differences would then be a remarkable coincidence, perhaps too remarkable to be plausible. ${ }^{123}$ It is at least equally likely that their jurisprudential differences merely reflect other traits that themselves are the driving force in their decisions. Moreover, as we have seen, an inspection of key cases in which the two disagree fails to show that jurisprudential differences are driving the results. The simplest - but not ironcladconclusion is that jurisprudence is having little direct effect on their votes.

This conclusion is reinforced by a more refined analysis of the data. En banc decisions confound the analysis presented earlier for three reasons. First, they are not randomly selected. Posner and Easterbrook disagree in a high proportion (about a quarter) of the en bancs. We cannot be sure of the direction of causation. Do they disagree so often simply because en banc cases are harder? Or are cases more likely to receive en banc review in the Seventh Circuit when the two disagree? Second, without a detailed statisti-

121 An $\mathrm{X}^{2}$ test indicates that this difference is not quite as statistically significant at the .05 level. $\left(X^{2}=7.19\right.$; one degree of freedom). For an explanation of this test including tables and formula, see

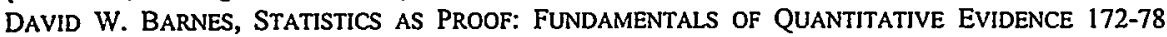
(1983). Thus, the slightly lower number of disagreements than average for the circuit, taken across all cases, is not large enough to prove that Posner and Easterbrook in fact are more likely to agree than average judges on their courts. But it seems clear that their unusually well-developed theoretical disagreement does not translate into any greater-than-average propensity to disagree on the results of cases. (As we will see, if we limit our attention to panel decisions as opposed to en banc decisions, the reduction in disagreement level below the circuit average is quite statistically significant. See infra note 124 and accompanying text.).

122 For recent discussions of the importance of ideology as a predictor of judicial voting, see Daniel R. Pinello, Linking Party to Judicial Ideology in American Courts: A Meta-Analysis, 20 JUST. SYS. J. 219 (1999); Richard Revesz, Ideology, Collegiality, and the D.C. Circuit: A Reply to Chief Judge Harry T. Edwards, 85 VA. L. REV. 805 (1999).

${ }^{123}$ If this effect does exist, it means that two randomly selected judges who have opposing jurisprudential views and an average degree of ideological difference might disagree as much as twice as often as judges with identical jurisprudential views-about $6 \%$ of the time, rather than $3 \%$. (This is a ceiling because we do not know how much of the base rate of $3 \%$ is due to jurisprudential differences between judges.) This is a significant, but not earth-shaking, effect- $94 \%$ of the time, two randomly selected judges would agree even though their jurisprudential views were opposite. 
cal analysis of the distribution of votes in en banc cases, we have no basis for comparing the Easterbrook/Posner divergence in those cases with that of randomly selected judges. Third, far fewer en bancs take place, making the chances of random error much greater.

If we eliminated en banc decisions, we are left with only 9 cases of disagreement out of 792 cases, or $1.1 \%$. On the Seventh Circuit generally, there were 15,081 cases, with 604 dissents, or $4 \% .{ }^{124}$ A $4 \%$ dissent rate translates into a $2.7 \%$ rate of disagreement by any two randomly selected judges. Thus, Posner and Easterbrook are less than half as likely to disagree with each other as other members of their court ${ }^{125}$ Apparently, their jurisprudential disputes do not much affect their votes. ${ }^{126}$

Indeed, in one respect these figures may overestimate the importance of theory. Of the 783 panel cases in which Posner and Easterbrook agree, at least a few may actually represent failure to follow the logic of their theories to divergent conclusions. That is, there may be at least a few cases where fully implementing their respective theories should have led to divergent results but did not do so. (Even if each judge correctly applies his theory $99 \%$ of the time, an almost inhuman level of infallibility, each would make a half-dozen mistakes in this group of cases.) By implicitly assuming away such possible defections from theory, the analysis may err in the direction of giving theory too much causal power.

Perhaps these results might not generalize to other judges. Easterbrook is far from being a simple-minded literalist, while Posner's pragmatism stresses the utility of clear rules in law. Conceivably, cruder forms of formalism and pragmatism, of the kind likely to be adopted by judges less capable than Posner and Easterbrook, might have more of an impact on outcomes. But this effect, if it exists, is likely to be countered by the fact that the average judge is much less interested in legal theory and much less likely to try to integrate theory into specific decisions. In short, if every judge in the country took a sincere oath of allegiance to textualism and formalism-or to dynamic interpretation and pragmatism-it seems quite possible that little or no detectable effect would exist on the outcomes of statutory cases.

This seems counterintuitive because we all know that the formalists on the Supreme Court, such as Thomas and Scalia, vote much differently than

124 I have excluded the nine cases where Posner and Easterbrook disagreed to avoid overlap with the earlier figure, but I included the other 783 cases on which they both sat because some contain dissents by other judges. This small adjustment has little effect on the ultimate figures.

${ }^{125} \mathrm{~A} \mathrm{X}^{2}$ test indicates that this difference is statistically significant at the .01 level. $\left(X^{2}=7.19\right.$; one degree of freedom). For an explanation of this test including tables and formula, see BARNES, supra note 120.

126 Nor, it should be noted, do they have any markedly greater propensity to disagree with other circuit judges who lack their theoretical grounding. Here, too, a Westlaw search puts them at or below the Seventh Circuit average. Although this suggests that their failure to dissent from each other is not unusual given their general relations with other judges, it also underscores the conclusion that having a well-developed theory of interpretation has little effect on actual votes. Textualist, pragmatic, and atheoretic judges all seem to vote much the same. 
the anti-formalists, such as Brennan and Stevens. What we really need to ask, however, is whether Thomas and Scalia would oppose each other more often if one of them became a pragmatist. And if Brennan or Stevens had embraced formalism, would they suddenly have begun voting with Scalia and Thomas in statutory cases? When we keep in mind that Justice Black was also a formalist, ${ }^{127}$ we are entitled to have doubts on this score.

So, have we all been wasting our time (and that of our students) by worrying about theories of statutory interpretation? The answer is no, for three reasons. ${ }^{128}$

First, the practical effect may be more important than I have indicated. I may be wrong in my evaluation of the effect of jurisprudential theories on Posner and Easterbrook, or in extrapolating to other judges. Even if the theories affect only the outcome of a few cases, those cases might turn out to be very important, like Weber. ${ }^{129}$ There might also be a snowball effect. For instance, if all judges were formalists, perhaps we would have small changes in results in the first generation of opinions, but the use of those opinions as precedents might increase the changes in the second generation of cases. ${ }^{130}$ So it may be a mistake to dismiss completely the potential effect of theory on case outcomes.

Second, we may not care merely about the outcomes of cases. We might also care about the language of opinions at a deeper level. In a formalist world, opinions tell us that judges are faithful servants of the statutory text, whose actions have no legitimacy without legislative warrant. In a pragmatist world, opinions tell us that judges are trying to do justice and improve society within the boundaries of governing legal directives. Even

${ }^{127}$ See Michael J. Gerhardt, A Tale of Two Textualists: A Critical Comparison of Justices Black and Scalia, 74 B.U. L. REv. 25, 29-33 (1994).

${ }_{128}$ In addition to the reasons given in the text, theories may provide useful frameworks for organizing arguments. This may be particularly helpful for students.

129 See United Steelworkers of Am. v. Weber, 443 U.S. 193 (1979) (upholding the legality of affirmative action under Title VII). Easterbrook could accept the legitimacy of Weber only if he viewed Title VII as a common law statute delegating lawmaking power to the courts. This is an arguable view of Title VII: it clearly describes how the Supreme Court has approached the statute, and it may be defensible because the statute draws on a judicially developed constitutional background while using openended terms such as "discrimination."

${ }_{130}$ Similarly, even when the two judges agreed as to result, they may have favored different legal rules that happened not to affect the result in a particular case. Application of those differing rules in later cases might then lead to different outcomes. See, e.g., In re Hoskins, 102 F.3d 311, 317 (7th Cir. 1996) (Easterbrook's concurrence rejects Posner's theory but agrees on the result because one party failed to cross-appeal); Czerkies v. United States Dep't of Labor, 73 F.3d 1435 (7th Cir. 1996) (en banc) (Posner holds for majority that district court had jurisdiction to consider claims regarding federal workers' compensation but that plaintiff's claim was insubstantial; Easterbrook concurs in judgment on basis that jurisdiction was lacking); E. I. DuPont de Nemours \& Co. v. Grasselli Employees Indep. Ass'n., 790 F.2d 611 (7th Cir. 1986) (Posner holds as part of majority that arbitral award could be reversed when it endangers public safety but finds no such threat; Easterbrook rejects public policies of this kind as a basis for judicial review of arbitration). Of course, such disagreements about the best rationale for a holding could arise between any two judges, regardless of their theoretical orientations. 
if the results are the same, the rhetoric is very different. Perhaps the rhetoric matters for its own sake, because of the message it sends about our system of governance.

Finally, it was Socrates who said that the unexamined life is not worth living. ${ }^{131}$ Even if it never changes the outcome of a single case, a judge or lawyer who never worries about the meaning of what she is doing is missing something. And as to scholars, some of us (perhaps most) would like to change the world. But there are also those who have a compulsion to try to understand it, regardless of practical consequences. If for no other reason, theories of statutory interpretation deserve our careful attention. But we should not expect the adoption of one theory or another by judges to transform legal doctrine.

131 See Robert Nozick, THE EXAMINEd LIFE: PhILOSOPHICAL MEditATIONS 15 (1989). 


\section{APPENDIX A}

\section{Cases in Which Posner and Easterbrook Disagreed}

The following cases are those in which Posner and Easterbrook have taken opposite sides, where one wrote or joined the majority opinion and the other wrote or joined a dissenting opinion. (In three of ten en banc cases in which both Judges dissented, each dissented separately. These cases are not included in the following list, however, since the judges differed in their reasoning, but not their votes.) For a description of the computer search methods used and their limitations, see Appendix B.

1. Edmond v. Goldsmith, 183 F.3d 659 (7th Cir. 1999).

Posner wrote the majority opinion; Easterbrook dissented. In a class action suit, the court held that drug roadblocks set up by the City of Indianapolis were unconstitutional in violation of the Fourth Amendment. The roadblocks did not fall within any existing exception to the principle that a search or seizure is forbidden by the Fourth Amendment unless there is a basis for believing that a particular search or seizure, as distinct from a program of universal or randomized searches or seizures, will yield evidence or fruits or instrumentalities of crime. Easterbrook found the roadblocks easily constitutional in light of related precedent and questioned, if the Constitution allows a roadblock to intercept alcohol users, how can it condemn a roadblock to intercept marijuana and cocaine users?

2. Adams v. Plaza Fin. Co., Inc., 168 F.3d 932 (7th Cir. 1999).

See Part II.A.1. Posner wrote the majority opinion; Easterbrook dissented.

3. United States v. Redmon, 138 F.3d 1109 (7th Cir. 1998) (en banc).

Easterbrook joined the majority opinion and a concurrence; Posner wrote a dissent and joined another. The court held that (1) a warrantless search of defendant's garbage cans located outside the attached garage of his townhouse did not violate the Fourth Amendment ${ }^{132}$ and (2) "the sentence enhancement under the career offender Sentencing Guidelines applies to statutory maximum as enhanced by prior convictions." defendant's curtilage, and so his conviction should be reversed."134

\footnotetext{
132 See Redmon, 138 F.3d at 1112-15.

133 Id. at 1115.

134 Id. at 1129.
} 
4. Salameda v. Immigration \& Naturalization Serv., 70 F.3d 447 (7th Cir. 1995).

Posner wrote the majority opinion; Easterbrook dissented. The court vacated an order of the Board of Immigration Appeals that denied discretionary suspension of deportation and held that the BIA could not disregard without explanation (1) hardship to non-citizen son of deportees and (2) deportee's community service. Although the issue involved the meaning of "extreme hardship," Posner wrote that the court decided not a question of statutory interpretation, but only whether the INS offered a rational justification. ${ }^{135}$ Easterbrook asserted that this was an easy case - that the Salamedas did not demonstrate that deportation would result in extreme hardship. ${ }^{136}$

5. Johnson v. Phelan, 69 F.3d 144 (7th Cir. 1995).

Easterbrook wrote the majority opinion; Posner dissented in part. The court affirmed the district court's dismissal of a pretrial detainee's $\S$ 1983 claim, and held that (1) reasonable monitoring of naked inmates does not violate the Fourth Amendment and (2) cross-sex monitoring neither violates due process nor constitutes cruel and unusual punishment. Posner disagreed that Supreme Court precedent addressed the issue and emphasized the dignity and respect due prisoners as fellow human beings.

6. Scariano v. Justices of Supreme Court of Ind., 47 F.3d 173 (7th Cir. 1995) (en banc).

In a case involving interstate practice of law, Posner wrote a dissent from the denial of rehearing en banc because he not only disagreed with the panel's holding, but also because the issue of interstate commerce is a particularly important responsibility of the federal judiciary. Easterbrook, who was not a member of the panel, voted to deny the rehearing en banc. (Arguably, Scariano should not be treated as a case of substantive disagreement since Easterbrook's failure to vote for an en banc might have involved factors other than his view of the merits, such as docket concerns.)

7. United States v. Nagib, 44 F.3d 619 (7th Cir. 1995), aff'd, 106 F.3d 404 (7th Cir. 1997), cert. denied, 521 U.S. 1127 (1997).

Easterbrook joined the majority opinion; Posner dissented. In an appeal based on ineffective assistance of counsel, the court remanded to allow the district court to determine whether defendant who was "con-

135 Salameda, 70 F.3d at 451.

136 See id. at 453-58.

137 See, e.g., Johnson, 69 F.3d at 152. 
victed of various drug offenses" "somehow consented to counsel's filing of late appeal." Posner wrote that the court should remand on the merits of the appeal, since Nagib clearly received ineffective assistance of counsel in his first appeal. ${ }^{138}$

8. United States v. Hudspeth, 42 F.3d 1015 (7th Cir. 1994) (en banc).

Easterbrook joined the majority opinion; Posner joined two opinions concurring in part and dissenting in part. The court held that (1) defendant's commission of crimes "committed on occasions different from one another" ("three distinct burglaries against owners of three distinct business enterprises in three separate locations over course of thirty minutes") made sentence enhancement provision of Armed Career Criminal Act applicable and (2) "recalculation of defendant's sentence enhancement initially vacated for insufficient record" did not violate the double jeopardy clause of the Fifth Amendment. One dissenting opinion argued that the meaning of the statutory language "occasions different from one another," is best determined by a "fact-bound, case-by-case method."139 The other dissenting opinion argued that finding the defendant a career criminal for breaking into a shopping mall and burglarizing three stores in thirty-six minutes was contrary to the intent of Congress. ${ }^{40}$

9. Resolution Trust Corp. v. Chapman, 29 F.3d 1120 (7th Cir. 1994).

Easterbrook wrote the majority opinion; Posner dissented. The court held that RTC's "negligence action against former directors and officers of a failed federally chartered savings and loan located in Illinois" "was governed by federal law" (because of the internal affairs doctrine), not Illinois law, and "by FIRREA, not federal common law." "[T]hus, RTC was required to show, at a minimum, gross negligence on part of directors and officers." Posner argued that the majority misinterpreted 12 U.S.C. $\S 1821(\mathrm{k})$ contrary to the intent of Congress to prevent states from shielding directors from liability, and thus that defendants could be held liable for simple negligence in accordance with state law. ${ }^{141}$ Moreover, he argued that the internal-affairs doctrine does not compel the application of federal law. ${ }^{142}$

10. United States v. Hollingsworth, 27 F.3d 1196 (7th Cir. 1994) (en banc).

Posner wrote the majority opinion; Easterbrook wrote a dissent, joined a second, and joined a third in part. In appeal of defendants convicted of money laundering and related offenses, the court held that (1) "pre-

agib, 44 F.3d at 623

Hudspeth, 42 F.3d at 1025.

140 See id. at 1027.

141 See Chapman, 29 F.3d at 1126.

142 See id. at 1126-27. 
disposition induced by government action cannot be used to defeat an entrapment defense"; (2) "the government failed to prove predisposition once the defendants raised colorable entrapment defense"; and (3) since one defendant acted as a government agent, "the second defendant was derivatively entrapped." Easterbrook argued that the majority misread Supreme Court precedent. ${ }^{143}$

11. Todd v. Societe BIC, 9 F.3d 1216 (7th Cir. 1993) (en banc).

Easterbrook wrote the majority opinion; Posner wrote an opinion dissenting in part and joined another. In appeal of summary judgment for the manufacturer of a butane lighter for a child's "death in fire started by another child who was playing with a lighter," the court held that the "warning emblazoned on lighter, "KEEP OUT OF REACH OF CHILDREN,' was sufficient." Further, "certification to Illinois Supreme Court was warranted to answer questions of whether 'consumer' for purposes of consumer contemplation test for finding defective product includes nonpurchasers who manufacturer should foresee will use or misuse product, and whether risk-utility test applies to consumer products whose risks can be appreciated by their intended users." Posner disagreed with the certification to the Illinois Supreme Court, arguing that it invited abstract answers that may not sufficiently assist with the case. ${ }^{144}$ Posner joined the portion of the majority opinion concerning warnings. ${ }^{145}$ After the Supreme Court of Illinois refused to hear the remainder of the case, both Easterbrook and Posner joined Judge Manion's majority opinion in Todd v. Societe BIC, S.A., 21 F.3d 1402 (7th Cir. 1994).

12. Bidlack v. Wheelabrator Corp., 993 F.2d 603 (7th Cir. 1993) (en banc), cert. denied, 510 U.S. 909 (1993).

Posner wrote the plurality opinion for three judges; three other judges concurred in the result; Easterbrook wrote a dissent for four judges. The court held that absence from collective bargaining agreements of any provision that explicitly vested benefits of retired employees did not defeat a claim, where agreements were ambiguous on the issue, and where contrary extrinsic evidence existed. Easterbrook argued that the only question before the court, to which the answer is no, was whether the retirees are entitled to medical benefits exceeding those of active workers.

13. Easter House v. Felder, 910 F.2d 1387 (7th Cir. 1990) (en banc).

Easterbrook joined the majority opinion and wrote a concurrence; Posner joined a dissent. In a $\S 1983$ claim by a private adoption agency

143 See Hollingsworth, 27 F.3d at 1211-13.

144 See Todd, 9 F.3d at 1225.

${ }^{145}$ See id. 
"alleging a conspiracy to deprive it of its operating license and harassment," the court held that the conduct was committed by a person acting under color of state law, that the agency had a property interest in the renewal of its license, but that it received all of the process that was due. Easterbrook's concurring opinion described inconsistent Supreme Court precedent, but agreed with the decision nonetheless. ${ }^{146}$ The dissent argued that recent Supreme Court precedent clearly compels an opposite result, given that the Court remanded the case for reconsideration of the procedural due process claim in light of that recent decision. ${ }^{147}$

14. United States v. Marshall, 908 F.2d 1312 (7th Cir. 1990) (en banc), aff'd sub nom., Chapman v. United States, 500 U.S. 453 (1991).

See Part III.B.2. Easterbrook wrote the majority opinion; Posner wrote a dissent and joined another.

15. Fox Valley \& Vicinity Constr. Workers Pension Fund v. Brown, 897 F.2d 275 (7th Cir. 1990) (en banc), cert. denied, 498 U.S. 820 (1990), reh' $g$ denied, 498 U.S. 993 (1990).

Posner joined the majority opinion; Easterbrook wrote one dissent and joined another. The court enforced a provision in a divorce agreement waiving a spouse's rights to death benefits under a pension plan. Easterbrook argued that the spouse's waiver should not be given effect because it would require the Fund to disregard its written-designation rule and would violate the spendthrift clause in ERISA, which states that "benefits provided under the plan may not be assigned or alienated."

16. United States v. Pino-Perez, 870 F.2d 1230 (7th Cir. 1989) (en banc), cert. denied, 493 U.S. 901 (1989).

See Part III.B.1. Posner wrote the majority opinion; Easterbrook wrote an opinion concurring and dissenting in part.

17. Torres v. Wisconsin Dept. of Health \& Social Servs., 859 F.2d 1523 (7th Cir. 1988) (en banc).

In a sex discrimination suit brought by "male correctional officers at a women's maximum security prison," Posner joined the majority opinion; Easterbrook wrote a dissent and joined another. The court "held that prison officials were asked to meet an ... unfair burden when they were required to produce objective evidence" supporting their theory that employing only female correctional officials in certain positions enhances rehabilitation. Easterbrook wrote that because the suit was pursuant to Title VII, not the Fourteenth Amendment, and because it

146 See Felder, 910 F.2d at 1408-10.

147 See id. at 1410 . 
involved overt gender classifications, the state bore the burden of persuasion and that it did not meet it. ${ }^{148}$

18. Newman-Green, Inc. v. Alfonzo-Larrain R., 854 F.2d 916 (7th Cir. 1988) (en banc), rev'd, 490 U.S. 826 (1989).

Posner wrote the majority opinion; Easterbrook wrote the dissent. In a suit by a manufacturer of aerosol valves against a Venezuelan corporation with which it had a contract, as well as four Venezuelans and one United States citizen, the majority concluded that a court of appeals may not dismiss a party in order to retain federal jurisdiction. However, the judgment was vacated and the case was remanded to the district court, which "retained authority to consider dismissal of nondiverse party to preserve diversity if no other parties would be harmed by such action." In dissent, Easterbrook emphasized the unnecessary resulting delays, as well as congestion, in the court system. ${ }^{149}$

19. Marozsan v. United States, 852 F.2d 1469 (7th Cir. 1988) (en banc), aff'd, 90 F.3d 1284 (7th Cir. 1996), cert. denied, 520 U.S. 1109 (1997).

See discussion, supra note 11; see also discussion, supra note 28. Posner joined the majority opinion and wrote a concurrence; Easterbrook wrote a dissenting opinion.

20. Jordan v. Duff \& Phelps, Inc., 815 F.2d 429 (7th Cir. 1987), cert. dismissed, 485 U.S. 901 (1988).

Easterbrook wrote the majority opinion; Posner dissented. The court reversed summary judgment for a closely held corporation in a fraud claim brought by a former shareholder-employee. It found triable issues regarding his claim that the company failed to disclose its prospect of being acquired before he quit and turned in his shares. Posner wrote that there was no violation of Rule $10 \mathrm{~b}-5$ because the terms of the stockholder agreement show that there was no duty of disclosure, and that the corporation had no duty to volunteer, to a corporate employee at will, information about the corporation's prospects that might have led him to change his mind about quitting. ${ }^{150}$

21. United States ex rel. Miller v. Greer, 789 F.2d 438 (7th Cir. 1986), cert. granted, 479 U.S. 983 (1986), rev'd, 483 U.S. 756 (1987), reh'g denied, 483 U.S. 1056 (1987).

Posner joined the majority opinion; Easterbrook wrote a dissent. In a federal habeas corpus petition by a defendant convicted of murder in

149 See Newman-Green, 854 F.2d at 927-28.

iso See Jordan, 815 F.2d at 444-45. 
state court, the court held that the prosecutor's reference to the defendant's silence following his arrest violated his right to a fair trial and constituted reversible error. Easterbrook found harmless error.

22. United States v. Green, 786 F.2d 247 (7th Cir. 1986).

Easterbrook wrote the majority opinion; Posner dissented. In appeal by defendant police officer convicted of mail fraud for using "required mailings to hit-and-run drivers as means of soliciting and accepting bribes," the court held that (1) truthful mailings can be a basis for conviction under the mail fraud statute; (2) "evidence of defendant's coworker's conviction for extortion was admissible"; and (3) prosecutor's innuendos against defense counsel were not basis for reversal. Posner argued that "Green neither committed mail fraud nor received a fair trial," "151 because he did not mail the letters "for the purpose of executing"' the scheme ${ }^{152}$ and because the prosecutor's misconduct was not harmless error. ${ }^{153}$

23. Wisconsin Knife Works v. National Metal Crafters, 781 F.2d 1280 (7th Cir. 1986).

See Part II.A.2. Posner wrote the majority opinion; Easterbrook dissented. 


\section{APPENDIX B}

\section{SEARCH METHODS USED TO DERIVE NUMERICAL RESULTS}

The following results were obtained by the specified Westlaw searches conducted on August 24, 1999. These statistics should be taken with a . grain of salt. Westlaw was not designed with this type of research in mind, so the search results are overinclusive in some respects and probably underinclusive in others. (For instance, due to an error by Westlaw in entering the judges' names into the database, the search did not find Miller v. Civil City of South Bend, ${ }^{154}$ a First Amendment case about nude dancing.) Also, the search did not identify cases such as Jansen v. Packaging Corp. $v$. America, ${ }^{155}$ in which both Posner and Easterbrook filed opinions concurring in part and dissenting in part, but for different reasons. Searches that did not specifically search for Posner and Easterbrook were limited to after 1985 , the year by which both had joined the court. Variances in results occur also because most, but not all, cases have synopses. ${ }^{156}$

\section{SEVENTH CiRCuIt (Database: CTA7)}

Cases in Which Posner and Easterbrook Have Sat Together

PA(POSNER \& EASTERBROOK)

En Banc Cases in Which Posner and Easterbrook Have Sat Together

PA(POSNER \& EASTERBROOK) \& SY("EN BANC")

Note: On inspection, fifty-three of these cases were en bancs. Judge Easterbrook reports that he and Judge Posner have sat together on eighty-two en banc cases.

Panel Cases in Which Posner and Easterbrook Have Sat Together

(POSNER \& EASTERBROOK) \& SY(COURT \% "EN BANC")

Cases in Which Posner and Easterbrook Disagreed

PA(POSNER \& EASTERBROOK) \& DIS(DISSENT! /S (POSNER OR EASTERBROOK))

154904 F.2d 1081 (7th Cir. 1990) (en banc), rev'd sub nom. Bames v. Glen Theater, 501 U.S. 560 (1991).

155123 F.3d 490 (7th Cir. 1997).

156 For this reason, for example, the search did not comrectly identify a few decisions as en banc, although no en bancs with opposing votes by Posner and Easterbrook were missed. 
Note: Of the twenty-three cases, fourteen were en banc. (The search result was thirty-five before examining for desired criteria. Ten of the twelve eliminated cases were en bancs in which both judges dissented. Recall that "disagreement" is considered disagreement in result, not disagreement in reasoning, so this count does not include cases in which Posner and Easterbrook voted the same way but for different reasons.)

\section{Total Cases}

DA(AFT 1985) \& COURT 16988

Total Cases (with synopses)

DA(AFT 1985) \& SY(COURT)

Cases with Dissents

DA(AFT 1985) \& DIS(DISSENT!)

En Banc Cases

DA(AFT 1985) \& SY(“EN BANC")

Note: This figure seems to contain a number of spurious cases.

Panel Cases

DA(AFT 1985) \& SY(COURT \% "EN BANC")

En Banc Cases with Dissents

DA(AFT 1985) \& SY(“EN BANC”) \& DIS(DISSENT!)

Panel Cases with Dissents

DA(AFT 1985) \& SY(COURT \% “EN BANC”) \& DIS(DISSENT!) 
NORTHWESTERN UNIVERSITYLAW REVIEW

\section{All Courts of APPEALS (Database: CTA)}

Total Cases

316010

DA(AFT 1985) \& COURT

Total Cases (with synopses)

175711

DA(AFT 1985) \& SY(COURT)

Cases with Dissents

9679

DA(AFT 1985) \& DIS(DISSENT!)

En Banc Cases

DA(AFT 1985) \& SY("EN BANC”)

Note: Thus, 314,602 (316,010 - 1408) cases were panels.

Panel Cases

174341

DA(AFT 1985) \& SY(COURT \% "EN BANC")

En Banc Cases with Dissents

713

DA(AFT 1985) \& SY(“EN BANC') \& DIS(DISSENT!)

Panel Cases with Dissents

8534

DA(AFT 1985) \& SY(COURT \% "EN BANC”) \& DIS(DISSENT!) 